\title{
Economic Implications of Education in Southeast Europe
}

\author{
Goran Popović ${ }^{1 *}$, Ognjen Erić1, Jelena Bjelić ${ }^{2}$ \\ 'University of Banja Luka, Faculty of Economics, Bosnia and Herzegovina; \\ e-mail: goran.popovic@ef.unibl.org; ognjen.eric@ef.unibl.org \\ ${ }^{2}$ Indirect Taxation Authority, Bosnia and Herzegovina, jelena.nemanjabj@gmail.com
}

\begin{abstract}
This research covers an evaluation of the impact of education system, educational, scientific and other institutions on the economic growth in nine countries of Southeast Europe (SEE). The main hypothesis is the following: GDP pc growth is significant and positively correlates with the indicators of the state of education system. In addition to educational institutions, there are other social and economic indicators on which education and science depend, namely the budget and fiscal system, corruption and protection of intellectual property rights, which also have positive and significant impact on GDP pc. The stated fields are interactive. Besides GDP pc, the analysis includes another 11 variables. Factor analysis for the variables grouped into two factors shows high significance. The F-test result shows significance of the regression model. ANOVA test, too, confirms the aforementioned significance. Both variables (the first and second factor) have positive direction with GDP pc. The results show significance of the institutional-educational variable, while the impact of educational population in the model is not sufficiently significant. Econometric analysis has mainly confirmed the initial hypotheses.
\end{abstract}

Keywords: Education system, institutions, budget, Southeast Europe, Economic growth, GDP.

\section{Introduction}

In theory, numerous factors affect the economic growth rate. This can be seen from the production function $Y=f(T p, C, L)$, where $Y-G D P$ value, $T p$ - technological progress, $C$ - capital, and $L$ - labour. The impact of education, science, technological development, research and innovations on GDP growth is sublimated into technological progress. And vice versa, the stated fields affect technological progress through knowledge accumulation, as well as GDP growth as a consequence of growth in labour and equipment (capital) productivity. The era of globalization is accompanied by an intensive economic development, which has become some kind of social paradigm. Modern definitions and new developmental approaches are stressing multidisciplinary approach all the more, because together with the nominal GDP growth (aggregate or pc), there occur in the observed period social, structural and technological changes. Today, economic development also has to meet the requirement of sustainability, which most often involves ecological, energetic and other natural factors and norms. The phrase "sustainable development" represents to many people concern for the environment, even though the concept of sustainability is much more complex. It is not difficult to notice that there are more and more requests for smart, inclusive and sustainable growth, which assumes that GDP growth $(Y)$ is occurring in a good (humane) social environment. And such an environment can only be realised by countries with developed institutions, including the policy of the entire education system. For example, the determinant "smart" is characterised by the processes of acquisition of new knowledge, even at lower educational levels, then studying, lifelong learning and other. EU member states have adopted the Europe 2020 strategy, through which they are applying the policy and standards of smart, sustainable and inclusive development.

Thus, smart growth is a privilege of those countries that have developed education systems (David, Goldin and Katz, 2020; Hanushek and Woessmann, 2020a) and which invest in research, development and innovations (Visvizi, Lytras and Daniela, 2018; Hanushek, 2016). Likewise, inclusive growth depends on the quality and quantity of the education system, especially in primary, secondary and tertiary education. Kochetkov, Larionova and Vukovic (2017) argue that role of the university does not simply conduct R\&D for business but creates essentially new industries and becomes the main actor

“Corresponding author: goran.popovic@ef.unibl.org 
of the economy. Prerequisites for smart and inclusive growth can be realised if there are developed and quality institutions in the field of education (Lilles and Rõigas, 2017; Nistor, Mera and Pop Silaghi, 2018). Therefore, the stated social systems are an important factor for economic growth, in particular the state of their development and organization, as well as social awareness. Hence, researching the impact of noneconomic factors on GDP growth is particularly important, not only for developed, but also for developing countries.

It is beyond dispute that the Southeast Europe countries find themselves on an economically and geographically unique territory. Regardless of the differences, most of them are undergoing important phases of economic and entire social development. It is here that the transitional processes, reforms, as well as resolution of the consequences of the world crisis 2008/2009 are of notable importance. Thereby, global economic order imposes the strictest norms in the area of competitiveness, export, ICT development and other (Milićević and Petrović, 2018; Petrović, Milićević and Djeri, 2017). It is important to note here that the regional countries are still facing "post-transitional" syndrome of insufficient growth rates. There arises a justified question: How can countries realise long-term GDP growth of minimally 4 to $6 \%$, creating conditions for larger investments in education system, scientific research, reforms and institution stabilisation?

The subject of this research is to determine the connection between education system, that is, educational, scientific and other institutions and economic growth, i.e. to determine their impact on GDP pc growth rate. The observed region is homogenous in terms of relevant indicators, economic and commercial, knowledge, culture and tradition. The analysis includes the following countries: Bulgaria, Romania, Croatia, Serbia, Bosnia and Herzegovina, Montenegro, Albania, Slovenia and Greece.

It is widely known that education, scientific research and technological progress affect the economic development and social welfare of post-transitional countries (Vuković et al., 2015; Popović et al., 2019). Even though the majority of the Southeast Europe countries have completed reforms of their education systems, developed and strengthened institutions (including educational institutions), harmonized policies and legislation with the EU, there are no visible effects on GDP pc growth yet. Besides that, the region is still trailing in EU's wake, despite the fact that assets are also invested for different purposes in research and education in the countries that find themselves in pre-accession stages (Popović and Erić, 2018). The European Union is helping to modernise public institutions, including various levels of education, as well as research and development. Together with the member states and candidates for membership, it is making efforts to modernise the education system, introduce modern methods and contents into the teaching process, as well as to optimise the duration of education process.

The complex character of economic growth and its interdependence with numerous factors have already been emphasised. Furthermore, many of them „overlap”. Education system, science and research depend to a great extent on the economic and institutional strength of a society, whereby the so-called other institutions that impact the balance between the budget and fiscal system (by stabilising debt and budget), as well as institutions for the protection of intellectual property rights, have a key role in this. And finally, it is important to reduce corruption, because this is one of the requirements for more efficient work of the institutions and faster welfare growth of this Euro-region.

Thus, the main hypothesis is that GDP pc growth stands in positive correlation with quantitative and qualitative indicators of the state of education system for the whole region of the Southeast Europe. In other words, their impact on economic growth is significant and positive. The results depend on institutions and policies for the creation and planning of education system development, as well as on the scientific-research base (Saviotti, Pyka and Jun, 2016; Astakhova et al., 2016). In addition to educational institutions, there are other social and economic indicators, on which the fields of education and science depend, that are important too; namely the following: the state of budget and fiscal system, corruption and intellectual property rights protection. What is in question are fields with strong interaction. The second aim of the research is to prove the hypotheses that these factors, too, have positive correlation with GDP pc growth, and that the connection between the observed variables is significant. It turned out that the developed economies or the economies of the developing countries have more efficient systems of education, science and research. The same holds for the economic welfare, which is inconceivable without continuous accumulation of knowledge arising from the education and scientific system (Benos, 2010).

Today, economic progress depends on the educational and scientific base, as well as on the synergic effect of the majority of institutions and numerous other factors (Hanushek and Woessmann, $2020 \mathrm{~b}$ ). Economic progress traditionally depends on the factors of available labour and capital, but also on the technological progress. It seems that this last factor is becoming all the more important, i.e. key for faster economic growth. The global market sees faster changes, dictated by new technological as well as 
organizational discoveries. Digitalisation sets the standards in all the social spheres. In terms of sectors, the following are all the more important: technological readiness, adoption of cutting-edge technologies, especially in IT, robotics, biotechnologies, microelectronics, new materials, etc.

With the aim of checking the hypotheses, the following variables have been used in the analysis, besides GDP pc: School Population Primary Education, School Population Secondary Education, School Population Tertiary Education, Critical Thinking in Teaching, Mean Years of Schooling, School Life Expectancy, Budget Transparency, Incidence of Corruption, Property Rights, Intellectual Property Protection and Debt Dynamics. The research makes use of various methods, with the econometric methods being the primary ones.

\section{Materials and methods}

Representative sample in the analysis comprises the Southeast Europe countries (the term being used in geographical sense). It is about the region that includes the following countries: Bulgaria, Romania, Croatia, Serbia, Bosnia and Herzegovina, Macedonia, Montenegro and Albania, whereby certain authors include Slovenia as well (Tache et al., 2017; Simionescu et al., 2016; Gouveia and Santos, 2018). But this research does not include Northern Macedonia, due to the lack of data in the World Economic Forum (WEF) Competitiveness Report for 2019. However, the sample includes Greece, as a country which has traditionally close economic, cultural, scientific and educational relations with the observed region. What stands out in particular is cooperation in the field of scientific research and similarity of education systems. Besides Greece, all the countries that are the subject of this research have undergone the process of transition from socialist to democratic-market systems. They are characterised by similar social circumstances and certain economic differences. All the countries are EU member states or are strategically determined for euro integrations and the European path towards democracy and market. Differences exist in the degree of EU integration (membership candidates and potential candidates, members of EU and monetary union).

The research is based on 12 variables that are presented in Table 1.

Table 1

Data for the analysis of observed phenomena

\begin{tabular}{lrrrrrr}
\hline Country & $* \mathrm{X}_{1}$ & $* \mathrm{X}_{2}$ & $* \mathrm{X}_{3}$ & $* \mathrm{X}_{4}$ & $* \mathrm{X}_{5}$ & $* \mathrm{X}_{6}$ \\
\hline ALB & 10,2 & 15,2 & 4,6 & 164 & 310 & 239 \\
B\&H & 9,7 & 14,3 & 2,5 & $\mathrm{~N} / \mathrm{A}$ & $\mathrm{N} / \mathrm{A}$ & $\mathrm{N} / \mathrm{A}$ \\
BGR & 11,8 & 14,8 & 3,5 & 276 & 488 & 374 \\
CRO & 11,2 & 15,0 & 2,3 & 170 & 357 & 240 \\
GRC & 10,3 & 17,9 & 2,7 & 687 & 661 & 561 \\
MNE & 11,2 & 15,0 & 3,6 & 39 & 65 & 43 \\
SRB & 11,1 & 14,8 & 3,6 & 270 & 567 & 404 \\
SVN & 12,3 & 17,4 & 4,8 & 120 & 129 & 104 \\
ROU & 11,0 & 14,3 & 2,7 & 1049 & 1704 & 1114 \\
Country & $* \mathrm{X}_{7}$ & $* \mathrm{X}_{8}$ & $* \mathrm{X}_{9}$ & $* \mathrm{X}_{10}$ & $* \mathrm{X}_{11}$ & $* \mathrm{X}_{12}$ \\
& & & & & & \\
ALB & 50 & 36 & 3,3 & 3,1 & 40 & 5,3 \\
B\&H & 35 & 38 & 3,3 & 2,9 & 50 & 5,6 \\
BGR & 66 & 42 & 3,9 & 3,7 & 80 & 9,3 \\
CRO & 57 & 48 & 3,8 & 3,8 & 80 & 14,8 \\
GRC & 53 & 45 & 4,0 & 4,0 & 50 & 20,4 \\
MNE & 54 & 45 & 4,3 & 3,9 & 40 & 8,6 \\
SRB & 43 & 39 & 3,9 & 3,7 & 50 & 7,2 \\
SVN & 69 & 60 & 4,6 & 4,8 & 100 & 26,2 \\
ROU & 75 & 47 & 4,6 & 4,7 & 79 & 12,3 \\
\hline & & & & & &
\end{tabular}

*X1 - Mean years of schooling, X2 -School life expectancy years, X3 -Critical thinking in teaching, X4 -School Population primary education in thousands, X5 -School Population secundary education in thousands, X6 -School Population Tercial

Education in thousands, X7 -Budget transparency, X8 -Incidence of corruption, X9 -Property rights, X10 -Intellectual property protection, X11 -Debt dynamics, X12 -GDP per capita thousands. 
Sources of data in Table 1 are the last available Global Competitiveness Report of the World Economic Forum (X1, X2, X3, X7, X8, X9, X10, X11) as well as the World Bank Development Indicators Report (X4, X5, X6, X12). It can be concluded on the basis of Table 1 that the values of indicators (variables) of all the countries are relatively homogenous in most cases. As for $\mathrm{BiH}$, there is a lack of data on school population, but the statistical techniques allowed (e.g. region averages attributed to the stated variables) make value approximations possible.

In order to test the set hypotheses, this paper makes use of several statistical-econometric techniques. One such technique is the Principal Component Analysis (PCA method). Calculation of the main components provides predictor variables by means of which the level of impact on the dependent variable, GDP per capita, is determined. In the analysis, the dependent variable, GDP per capita, is actually the proxy variable of the Southeast Europe economic development.

Multivariate factor analysis used is a set of statistical and mathematical procedures which can be utilized to determine the dependence between the observed phenomena (variables). It is important to note here that growth in the number of variables causes greater need for knowing their structure and interrelations. This paper makes use of the PCA technique based on variances, whereby the problem dimension is reduced, and maximum possible variability is kept. The initial variables are transformed into linear combinations of the original variables, in order to include an all the greater part of the variance of the original variable set (Vidal et al., 2016).

Factor analysis is conducted in four steps: evaluation of the justification of factor analysis, extraction, factor rotation and calculation of factorial scores. In principle, this analysis is the technique of decreasing the amount of data by reducing the original set of variables onto a set of small number of factors, whereby another, not directly perceptible dimension is identified. This smaller number of variables makes interpretation of results easier. Variants (components) are formed to maximise the whole set of variables, not to predict the dependent variable (variables). Stock and Watson $(1998,2002)$ have researched factor analysis and estimates of macroeconomic variables.

The form of the factor analysis equation reminds one of multiple linear regression that is used in the second part of the analysis:

$$
X_{i}=A_{i 1} F_{1}+A_{i 2} F_{2}+A_{i 3} F_{3}+\ldots+A_{i m} F_{m}+V_{i} U_{i}
$$

where:

- i-standardised variable,

- standardised coefficient of multiple regression of variable "i" to joint factor "j",

- joint factor "j",

- standardised regression coefficient of variable "i" to "unique" factor "i",

- "unique" factor for the variable "i",

- number of joint factors.

Each variable is a linear combination of extracted factors ( ), and part of the "unique" for each variable ( ).

Joint factors can be expressed as linear combinations of the observed variables, that is:

where:

$$
F_{i}=W_{i 1} X_{1}+W_{i 2} X_{2}+W_{i 3} X_{3}+\ldots+W_{i k} X_{k}
$$

- estimation of i-factor,

- weight or factor "score" coefficient,

- number of variables.

Such analyses are mainly used to determine whether independent variables explain significant part of the variability of dependent variables, that is, to determine the part of variability of the dependent variable, explained in terms of one or more independent variables.

Software solutions increase the efficiency of factor models. This paper uses the software application SPSS, Version 26. 


\section{Results}

The following table presents descriptive statistics; there exists significant standard deviation from the average in the data related to the school population at all three levels of education. This, at the same time, is a logical indicator, because the countries have varying populations (Montenegro minimum, Romania maximum in the sample). Analysis of other variables in the table of descriptive statistics does not show marked deviations.

\section{Table 2}

Descriptive Statistics

\begin{tabular}{lccc}
\hline & Mean & Std. Dev. ${ }^{\mathrm{a}}$ & $\begin{array}{c}\text { Analysis } \\
\mathrm{N}^{\mathrm{a}}\end{array}$ \\
\hline $\begin{array}{l}\text { School Pop., } \\
\text { Primary Educ., thousands }\end{array}$ & .33 & .33 & 9 \\
$\begin{array}{l}\text { School Pop., } \\
\text { Secondary Educ., } \\
\text { thousands }\end{array}$ & .51 & .48 & 9 \\
$\begin{array}{l}\text { School Pop, } \\
\text { Terciary Educ., } \\
\text { thousands }\end{array}$ & & & \\
$\begin{array}{l}\text { Mean years of } \\
\text { schooling }\end{array}$ & .37 & .32 & 9 \\
$\begin{array}{l}\text { School life } \\
\text { expectancy }\end{array}$ & 11 & .81 & 9 \\
$\begin{array}{l}\text { years } \\
\text { Critical thinking } \\
\text { in teaching }\end{array}$ & & & \\
$\begin{array}{l}\text { Budget } \\
\text { transparency }\end{array}$ & 15.41 & 1.31 & 9 \\
$\begin{array}{l}\text { Incidence of corruption } \\
\text { Property rights }\end{array}$ & 3.37 & .90 & 9 \\
$\begin{array}{l}\text { Intellectual property protection } \\
\text { Debt dynamics }\end{array}$ & 55.78 & 12.7 & 9 \\
\hline
\end{tabular}

The following table shows the degree of explanation of the variance of the analysed variables grouped into two components (factors). The first component (factor) explains $45,46 \%$ of the fluctuations of all the variables, and the second one explains $32.3 \%$, which is statistically highly significant and satisfies the conditions for continuing the analysis, as cumulatively both factors explicate over $77 \%$ of variations in all the variables.

\section{Table 3}

Total Variance Explained

\begin{tabular}{|c|c|c|c|c|c|c|}
\hline Compon. & & itial Eige & yvalues & Rotati & n Squared & Sums of Loadings \\
\hline & Tot. & $\%$ Var. & Cumul. \% & Tot. & $\%$ Var. & Cumul.\% \\
\hline 1 & 5.2 & 47.3 & 47.3 & 5.0 & 45.4 & 45.4 \\
\hline 2 & 3.3 & 30.4 & 77.7 & 3.5 & 32.3 & 77.7 \\
\hline
\end{tabular}

What follows is a representation of factor loading matrix, after factor rotation which shows the explanation coefficients for the variables of each selected factor. The first column contains shaded variables with the first component (the first factor) being the dominant one, whereas the second column contains variables which are better represented by the second factor. 


\section{Table 4}

Rotated Component Matrix

\begin{tabular}{lll}
\hline & \multicolumn{2}{c}{ Component } \\
& \multicolumn{1}{c}{1} & \multicolumn{1}{c}{2} \\
\hline School Pop., & .192 & .945 \\
Primary Educ., & & \\
thousands & & \\
School Pop., & .136 & .975 \\
Secondary Educ., & & \\
thousands & & \\
School Pop, & .107 & .979 \\
Terciary Educ., & & \\
thousands & & \\
Critical thinking in teaching & .316 & -.592 \\
Mean years of schooling & .859 & -.258 \\
School life expectancy years & .461 & -.266 \\
Budget transparency & .853 & .319 \\
Incidence of corruption & .921 & -.132 \\
Property rights & .883 & .239 \\
Intellectual property & .934 & .277 \\
protection & & \\
Debt dynamics & .810 & .085 \\
\hline
\end{tabular}

Extraction Method: Principal Component Analysis.

Rotation Method: Varimax with Kaiser Normalization. a. Rotation converged in 3 iterations.

Variations in school population in primary, secondary and tertiary education are better explained by the second factor (positive direction), and the same holds for the variables of critical thinking in teaching (negative direction). On the other hand, the variables of institutional character, mean years of schooling and school "life" expectancy are significantly explained by the first factor. In further analysis, the components will be renamed according to the kinds of variable.

The first component is given the name Institution-Education Variable, and the second one School Population. Both of the formed variables are defined as independent in the evaluation of the impact on economic development (the level of GDP per capita). The first section shows the result of summary statistics for the countries in the sample (Table 5), where the determination coefficient is R2 $=0,74$, which means that $74 \%$ of variations of GDP per capita is explained in terms of joint impact of the independent variables in the model. With the F test result of 7,6 and probability level below $5 \%$ i.e. 3,7, it is obvious that there is significance of the formed regression model.

\section{Table 5}

Model Summary

\begin{tabular}{rrrrr}
\hline Model & $\mathrm{R}$ & $\mathrm{R}^{2}$ & Adj. $\mathrm{R}^{2}$ & $\begin{array}{l}\text { Std. Error of } \\
\text { the Estimate }\end{array}$ \\
\hline 1 &, $86^{\mathrm{a}}$ &, 74 &, 65 & 4,24 \\
\hline
\end{tabular}

a. Predictors: (Constant), Institucon-Education Var., Educational population b. Dependent Variable: GDP per capita thousands

The same conclusions are indicated by the second section of the regression analysis of variance (ANOVA) in Table 6. Calculated sums of squared deviations of regressors, residuals and total value for the given freedom degrees confirm the significance of the results of the observed model. 


\section{Table 6}

ANOVAa

\begin{tabular}{llccccc}
\hline & Model & $\begin{array}{c}\text { Sum of } \\
\text { Squares }\end{array}$ & df & $\begin{array}{c}\text { Mean } \\
\text { Square }\end{array}$ & F & Sig. \\
\hline 1 & Regression & 299,891 & 2 & 149,945 & 8 &, $02^{b}$ \\
& Residual & 107,846 & 6 & 17,974 & & \\
& Total & 407,736 & 8 & & & \\
\hline
\end{tabular}

a. Dependent Variable: GDP per capita thousends

b. Predictors: (Constant), Institucon-Education Var., Educational population

The following section (Table 7) shows the results of individual impact of independent variables in the model. The Institution-Education variable has positive direction in explaining the dependent variable trends (GDP per capita) with high value of the coefficient $(6,06)$, and the value of $t$ statistics $(8,621)$. The results point to the conclusion that there is individually significant impact of the variable InstitutionEducation, as the obtained probability is below the cut-off value of $5 \%(0,7 \%)$.

Even though the impact of Education Population in the model is of positive direction, with the coefficient of 0,827 , statistically it has not been assessed as significant in explaining the fluctuations of the dependent variable at the statistical significance level of $5 \%$.

\section{Table 7}

Coefficientsa

\begin{tabular}{lcccc}
\hline \multicolumn{1}{c}{ Model } & \multicolumn{2}{c}{$\begin{array}{c}\text { Unstandardized } \\
\text { Coefficients }\end{array}$} & t & Sig. \\
& $\mathrm{B}$ & Std. Error & & \\
\hline (Constant) & 12,183 & 1,413 & 8,621 &, 000 \\
Institucon- & 6,06 & 1,499 & 4,047 &, 007 \\
Education Var. & & & & \\
Educational population &, 827 & 1,499 &, 552 &, 601 \\
\hline
\end{tabular}

a. Dependent Variable: GDP per capita thousends

\section{Discussion}

The Balkan and Southeast Europe countries have undergone transitional processes. Currently, with larger investments in the development of education and research, as well as building and reforming all institutions, they, as members or candidate members, are trying to speed up the economic growth. The majority of economically, educationally, geographically, culturally and traditionally similar countries of Southeast Europe are reforming their education systems, developing and strengthening educational and other institutions, while in parallel harmonising standards and legislation with the EU. Still, despite numerous measures, the region is not showing perceptible indicators that point to dynamics and stability of economic growth rates.

It has been said that the modern aspects of social development are complex and multidisciplinary. To the main, economic and technical-technological factors there can be added the educational factor, which is becoming an important factor of economic development (it has been pointed out in the development function that it can be interpreted through technical progress - Tp). No less important for the economic development are institutional factors, intellectual property rights protection, state in the corruption sphere, as well as budgetary and fiscal stability. The majority of the stated factors is in strong interaction, and it is on them that the economic development, but also wider social structural and other changes depend.

There is a growing number of countries that are adopting and implementing the policies of smart, 
inclusive and sustainable development and growth (that is, increase in GDP pc), which is taking place in humane social environment. Such a developmental approach is also being implemented by the European Union, which has accepted the standards of sustainable, smart and inclusive growth through the implementation of the Europe 2020 strategy. It is more than obvious that smart development is based on modern and developed education system, and investment into research, development and innovations. Smart development is actually the process of continuous accumulation of new knowledge in all the resources of the education system. Education subsystems, namely primary, secondary and tertiary education, are bound with inclusive growth too. This means that social engagement depends to a larger extent on the quantity and quality of the education system.

The initial results of the econometric analysis show that there is more significant standard deviation from the average only in the data related to the school population at all three levels of education, which is explainable in terms of differences in the size of the population. Other variables do not show significant statistic deviations.

Factor analysis shows high level of explanation of the variance for the variables which have been grouped into two factors. The first factor explains $45,46 \%$, and the second one $32.2 \%$ of the fluctuations of all the variables, which is statistically highly significant, because taken together, both factors explain over $77 \%$ of the variations of all variables. After factor rotation which shows the coefficients of explanation of the variables for every one of the selected factors, the factor loading matrix was formed.

The first column contains the variables where the first component (the first factor) is the dominant one, while the second contains the variables that are better represented by the second factor. The research has shown that the institutional variables, mean years of schooling and school life expectancy are significantly explained by the first factor. The second factor better explains the variations in school population in the primary, secondary and tertiary education, which have positive direction. The same holds for the variable that is explained by the indicator of the state of critical thinking in teaching, but the only thing is that this variable has negative direction.

On the basis of the obtained results and variable characteristics, the factors were renamed. The first factor was named Institution-Education variable, whereas the second one was named School Population. De facto, two new independent variables were formed in the assessment of the impact on the growth of GDP pc.

The first section in the remaining part of the research shows that the determination coefficient amounts to $\mathrm{R} 2=0,74$, meaning that $74 \%$ of the variations of the dependent variable, GDP pc, is explained by joint impact of the independent variables in the model. $F$ test results of 7,6 and the probability value below $5 \%$ i.e. 3,7 show significance of the regression model. Regression variance analysis (ANOVA), sums of squared deviations of regressors, residuals and total values for the given freedom degrees, confirm the significance of the selected model.

There are multidisciplinary studies in the fields of education, science, institutions and economic growth. However, there are few researches and studies that deal with the problems of post-transition countries of the analyzed geographical area, as in this paper.

The research into individual impact of independent variables in the model shows that the institutioneducation variable is significant. This result is in agreement with the research conducted by Nistor et al., (2018), who proved that the economic progress depends on the synergy of key institutions and other factors. The results also comply with the research carried out by Lilles and Rõigas (2017), who proved that conditions for the implementation of smart and inclusive growth depend on educational institutions. This confirms that the education system (and the system of other activities) is a factor of economic growth in SEE countries. Individual impact of the education population in the model is not sufficiently significant. But both variables (the first and second factor) have positive direction in explaining variations of the dependent variable, GDP $p c$.

The relevance of the models that base economic growth on knowledge (Hanushek and Woessmann, 2020a), research, development and innovations (Visvizi, Lytras and Daniela, 2018; Hanushek, 2016) has been indirectly proven.

\section{Conclusions}

The initial hypothesis in this research is that economic growth is significant and that it positively correlates with the state of education systems of this region's countries. The hypothesis that the indicators of the state of educational and other institutions positively correlate with the growth of GDP pc has been tested as well. For the purpose of proving, this paper makes use of econometric analysis, where, beside GDP pc, the following variables have been used: School Population Primary Education, School Population 
Secondary Education, School Population Tertiary Education, Critical Thinking in Teaching, Mean Years of Schooling, School Life Expectancy, Budget Transparency, Incidence of Corruption, Property Rights, Intellectual Property Protection and Debt Dynamics.

The applied methodology is also possible for other combinations of educational and scientific research factors. Factor analysis is an optimal tool for assessing the interrela-tionships between a large numbers of different social indicators. Econometric analysis confirms to a great extents the initial hypotheses that the state of education system and institutions correlates with the economic growth of the SEE countries.

Segments of the education system are placed in the context and interaction with economic growth in this research, and the obtained results represent a research novelty. The choice of institutional factors in combination with the above represents an additional degree of novelty. The research novelty of the paper is the breadth of geographical space and differences in the level of development of a group of different countries, which largely depends on the correct choice of model.

In accordance with the obtained results, it is possible to suggest the following recommendations:

- Southeast Europe countries need to improve cooperation in the field of education. When it comes to education, there should be expanded the existing forms of cooperation in higher education, paying respect to the interests of the region and EU. The same holds for cooperation in the field of science and research. The priorities are standardization and quality.

- Cooperation should also be developed in the field of secondary education. Given the freedom of workforce movement in the region, it seems justified for the SEE countries to cooperate in this field as well. This pertains to technical, medical, IT and other vocations. The priorities are standardisation and quality of education.

- Cooperation with the European Union should be strengthened in terms of participation in Euro funds. What presents a challenge are participations in larger scientific-research projects.

- The aim is to strengthen public institutions, particularly educational and scientific ones. Public institutions impact macroeconomic and budgetary balance and create assumptions for the growth of investment in education, science and research. Their share in GDP (except Slovenia and Greece) is, currently, several times lower than the EU average.

\section{Acknowledgements}

We are grateful to the Faculty of Natural Sciences and Mathematics, University of Banja Luka for their unselfish support in all stages of this research. Nevertheless, we owe special thanks to our colleagues at the International Economic Relations Department, Faculty of Economics, University of Banja Luka.

\section{Conflict of interests}

The authors declare no conflict of interest.

\section{References}

Astakhova, K. V., Korobeev, A. I., Prokhorova, V. V., Kolupaev, A. A., Vorotnoy, M. V., \& Kucheryavaya, E. R. (2016). The role of education in economic and social development of the country. International Review of Management and Marketing, 6(1S). Available at: https://www.econjournals.com/index.php/irmm/article/view/1865/pdf

Benos, N. (2010). Education policy, growth and welfare. Education Economics, 18(1), 33-47. https://doi. org/10.1080/09645290802500263

Bouhajeb, M., Mefteh, H., \& Ammar, R. B. (2018). Higher education and economic growth: the importance of innovation. Atlantic Review of Economics: Revista Atlántica de Economía, 1(2), 4. Available at: http:/laroec.org/ojs/index.php/ ARoEc/article/view/58

David, H., Goldin, C., \& Katz, L. F. (2020). Extending the Race between Education and Technology. NBER Working Paper, (w26705). https://doi.org/10.3386/w26705

Gouveia, S., \& Santos, M. (2018). Export Performance of Southeastern European Countries. In Economy, Finance and Business in Southeastern and Central Europe (pp. 195-211). Springer, Cham. https://doi.org/10.1007/978-3-319-70377-0_14

Hanushek, E. A. (2016). Will more higher education improve economic growth?. Oxford Review of Economic Policy, 32(4), 538-552. https://doi.org/10.1093/oxrep/grw025

Hanushek, E. A., \& Woessmann, L. (2020a). Education, knowledge capital, and economic growth. In The Economics of Education (pp. 171-182). Academic Press. https://doi.org/10.1016/B978-0-12-815391-8.00014-8

Hanushek, E. A., \& Woessmann, L. (2020b). A quantitative look at the economic impact of the European Union's educational goals. Education Economics, 1-20. https://doi.org/10.1080/09645292.2020.1719980

Kochetkov, D. M., Larionova, V. A., \& Vukovic, D. B. (2017). Entrepreneurial capacity of universities and its impact on regional economic growth. Economy of Region/Ekonomika Regiona, 13(2), 477-488 https://doi.org/10.17059/2017-2-13

Lilles, A., \& Rõigas, K. (2017). How higher education institutions contribute to the growth in regions of Europe?. Studies in Higher Education, 42(1), 65-78. https://doi.org/10.1080/03075079.2015.1034264 
Milićević, S., \& Petrović, J. (2018). Human resources in the function of European Union competitiveness as tourism destination. BizInfo (Blace) Journal of Economics, Management and Informatics, 9(2), 53-63. https://doi.org/10.5937/ bizinfo1802053M

Nistor, S., Mera, V. I., \& Pop Silaghi, M. I. (2018). Is education important in assessing the impact of institutions on economic growth in emerging economies?. Applied Economics, 50(34-35), 3840-3854. https://doi.org/10.1080/00036846.2018. 1436149

Petrović, J., Milićević, S., \& Djeri, L. (2017). The information and communications technology as a factor of destination competitiveness in transition countries in European Union. Tourism Economics, 23(6), 1353-1361. https://doi. org/10.1177/1354816616653529

Popović, G., \& Erić, O. (2018). Economic development of the Western Balkans and European Union investments. Economic research-Ekonomska istraživanja, 31(1), 1539-1556. https://doi.org/10.1080/1331677X.2018.1498009

Popović, G., Erić, O., Stanić, S. \& Krajišnik, M. (2019). Education, technological changes and economic development of Bosnia and Herzegovina, International Journal of Cognitive Research in Science, Engineering and Education (IJCRSEE), 7(2), 77-86. https://doi.org/10.5937/IJCRSEE1902077P

Saviotti, P. P., Pyka, A., \& Jun, B. (2016). Education, structural change and economic development. Structural Change and Economic Dynamics, 38, 55-68. https://doi.org/10.1016/j.struec0.2016.04.002

Simionescu, M., Ciuiu, D., Bilan, Y., \& Strielkowski, W. (2016). GDP and net migration in some eastern and south-eastern countries of Europe. A panel data and Bayesian approach. Montenegrin Journal of Economics, 12(2), 161-175. https:/l doi.org/10.14254/1800-5845.2016/12-2.10

Stock, J. H., \& Watson, M. W. (1998). Median unbiased estimation of coefficient variance in a time-varying parameter model. Journal of the American Statistical Association, 93(441), 349-358. https://doi.org/10.1080/01621459.1998.10474116

Stock, J. H., \& Watson, M. W. (2002). Macroeconomic forecasting using diffusion indexes. Journal of Business \& Economic Statistics, 20(2), 147-162. https://doi.org/10.1198/073500102317351921

Tache, I., Bratucu, G., Chitu, I. B., \& Dovleac, L. (2017). Improving the relationship between higher education institutions and business environment in South-Eastern Europe: a case study. International Journal of Economics and Business Administration, 5(2), 3-13. Available at: https://www.um.edu.mt/library/oar/handle/123456789/43214

Vidal, R., Ma, Y., \& Sastry, S. S. (2016). Principal component analysis. In Generalized principal component analysis (pp. 2562). Springer, New York, NY. https://doi.org/10.1007/978-0-387-87811-9_2

Visvizi, A., Lytras, M. D., \& Daniela, L. (2018). Education, innovation and the prospect of sustainable growth and development. In The future of innovation and technology in education: Policies and practices for teaching and learning excellence. Emerald Publishing Limited, pp. 297-305. https://doi.org/10.1108/978-1-78756-555-520181015

Vuković, D. B., Shpak, N. A., Radovanović, M. M., Portugal Duarte, A., \& Radulović, D. (2015). The role of human resources on the economy: a study of the balkan EU member states. Journal of the Geographical Institute 'Jovan Cvijic 'SASA, 65(2). pp.253-268. https://doi.org/10.2298/IJGI1502123V

World Economic Forum (2020). The global competintiveness reports 2019. World Economic Forum Geneva. Retrieved from: http://www3.weforum.org/docs/WEF_TheGlobalCompetitivenessReport2019.pdf 